the next day I was well except for some pains in the joints, which persisted for nearly a week.

Now the main interest of the case lies in the fact that in 1902 I was not susceptible to the toxic action of the serum; in $1909 \mathrm{I}$ was intensely so. The serum of the latter date was not toxic in itself, as shown by its lack of action in the case of both patient and interne-ergo it would seem as though I had been activated by the first dose and remained so after a period of seven years.

We clearly need the aid of a careful investigation into the question of time limit. It may well be that my experience was not so exceptional as it appears.

H. D'Arcy Power, M.D, San Francisco.

\section{Delegates for Pharmacopeia Convention}

To the Editor:--In accordance with the provisions of Artic.e VIII, Chapter 1, of the by-laws of the U. S. Pharmacopeial Convention, the president of the convention hereby invites the several bodies, entitled under the constitution to representation therein, to appoint delegates to the first decennial meeting of the said convention to be held in the City of Washington, May 10, 1910.

The attention of all concerned is invited to the following extract from the constitution from Article II on membership:

Section 1. The members of the United States Pharmaropeial Convention, in addition to the incorporators and their associates, shall be delegates elected by the follow ing organizations in the manner they shall respectively provide: incorporated medical colleges and medical schools connected with incorporated colleges and universities; incorporated colleges of pharmacy, and pharmaceutical schools connected with incorporated universitie': incorporated state medical associations; incorporated state pharmaceutical associations; the American Medical Association, the American Pharmaceutical Association. and the American Chemical Society; provided that no such organization shall be entitled to representation unless it shall have been incorporated within and shall have been in continuous operation in the United States for at least five years before the time fixed for the decennial meeting of this corporation.

Sectron 2. Delegates appointed by the Surgeon-Gener, of the United States Army, the Surgeon-General of the United States Navy, and the Surgeon-General of the United States Marine-Hospital Service. and by the organizations not hereinbefore named which were admitted to representation in the convention of 1900 shall also be members of the corporation. Each body and each branch of the United States Government above mentioned shall be entitled to send three delegates to the meetings of this corporation. But no such delegates as are provided for in this article shali be members until their credentials shall have been examined and acted on as provided for by the by-laws. Delegates admitted as members at any decennial meeting shall continue to be members of the United States Pharmacopeial Convention until their successors shall have been appointed and admitted as delegates to the ensuing convention, and no longer.

Notification of the appointment of delegates, accompanied by the necessary certification of eligibility as required by Article II, Section 1, of the constitution above quoted, should be forwarded as soon as practicable to the secretary of the Board of Trustees.

Horatro C. WOOd, M.D., Philadelphia, President.

Murray Galt Motter, M.D., Secretary of the Board of Trustees, 1841 Summit Place, Washington, D. C.

\section{Miscellany}

Care of Weak Infants and Children.-That something more than temporary relief or routine institutional care is necessary to improve the defective vitality of the sick and ailing infants of the poor and combat the influence of their wretched environment is quite evident from the indifferent results obtained from ordinary methods. Dr. Henry Dwight Chapin (Charities and The Commons, March 27, 1909) describes the methols adopted by the Speedwell Society in caring for this class of children. The plan followed is the boarding-out sys. tem, and the results have been remarkalbly good considering that bottle-feeding has been employed exclusively. The children have been placed in carefully selected homes in a health. ful location. A physician and a trained nurse have oversight of the cases. The foster-mother is instructed in the feeding and care of the baby and receives $\$ 12$ a month as compensation. Many take a great interest in the work and are very successful in nursing feeble infants back to health. Some tire of the work and others are dropped because of inefficiency, but the aim is to retain we same families in the work so far as practicable. Dr. Chapin says: "The boarding-out method, under careful supervision in the country, is the best plan yet devised to relieve and save these infants. The first series of 121 cases would nearly all have died under ordinary methods of handling and yet nearly two-thirds of them were saved. They were poorly nourished, from bad hygienic surroundings, with various degrees of digestive disturbances from faulty feeding on the bottle, and stationary or losing weight. A large proportion were restored to fair and even vigorous vitality, although kept on the bottle. The greater number of those from three to six months to one year was saved, in the first series nearly three-quarters being the proportion. These are brilliant results considering that artificial feeding and was still of necessity exclusively employed."

Medical Statistics for European Russia in 1906.-The St. Petersburg. med. Wochenschrift, March 27, published the vital statistics and public health reports just issued for 1906 . The total mortality is stated to have been 29.2 per thousand inhabitants, the births 45.9 per thousand. There were 17,096 eivilian physicians, 21,670 "feldshers," 11,032 midwives, 4,917 dentists, and 8,828 pharmacists, to a population of $106,114,589$. The number of sick treated in hospitals during the year was $2,458,207$, with a mortality of 5.2 per cent. There were 133 asylums for the insane, with 30,671 beds and 566 maternities or obstetric wards with 4,755 beds, and a record of 178,877 deliveries, with a mortality of 0.5 per cent. There are 20 Pasteur institutes, and 19,668 persons were given Pasteur treatment during the year, of whom 106 died. There were 178 medical societies and 44 hygienic laboratories. The total outlay for medical purposes was $\$ 38,760,000 \quad(76,000,000$ rubles). Of this 7 per cent. was borne by the central and 50 per cent. by the provincial treasuries, 24 per cent. by the cities and 17 per cent. by private individuals and societies.

Appendicitis in Childhood.-In Hygiea Festband, Carlson discusses acute appendicitis during the first fifteen years of life on the basis of 47 original cases. He believes that appendicitis is more serious in children than in adults, because it more often passes over into diffuse peritonitis, because changes in the appendix more often are gangrenous and be. cause the septic form is relatively common. The death rate in his cases has been much greater than in the case of adults, the probable reason being that the children have been seen too late for operation. Every child diagnosed to have appendicitis during the first 24 hours of sickness should be operated on before the end of that time. Operation is also indicated during the second 24 hours. During the third, fourth and fifth days operation should be made in every case that does not show definite and persistent signs of improvement; but it is to be remembered that during this later period the operation is technically much more difficult. After the first attack operation should be made in the free interval. The points on which Carlson lays special emphasis are the great danger of appendicitis in children and the necessity of early and correct diagnosis-not an easy task--so that operation may be done as early as possible during the first attack.

Experimental Researches on Some Ferments of the Bile.G. Bonanno (Arch. di farm. sper. e sc. aff., vii, 466) finds that the bile of the human being, of pigs, dogs, sheep and calves always possesses amylolytic and lipolytic properties, but no proteolytic action. The amylolytic action is stronger in the bile of herbivora than omnivora, while the lipolytic is about the same for all. Bile from either animal after the addition of pieces of duodenal mucosa shows no proteolytic action. 